\title{
BETWEEN APOLOGY AND REFUSAL, BETWEEN PERSUASION AND MANIPULATION - ANDREJ HLINKA IN THE FORMING OF THE INSTITUTIONALIZED MEMORY OF THE SLOVAK COMMUNITY II
}

\section{ABSTRACT}

Changes in evaluation of Andrej Hlinka when making efforts to form systemically the thinking of children and adolescents have in principle the same stages and milestones as the milestones of writing about Hlinka in the Slovak historical science, however, the dispute with respect to Hlinka in the area of education reached more remarkable even bizarre dimensions. This is proven by differences between official texts of school textbooks, teaching aids published in the period of 1919-2013 and individual memory of adolescents which can be found in the whole above mentioned period in spite of the absence of relevant sources.

Textbooks of interwar national (state) schools are characterized in particular by neglecting Hlinka, which is clearly visible when comparing the representation of other much less significant personalities of the modern Slovak history in their texts; however, we cannot state that this fact was affected only by the period doctrine (Czechoslovakism and republicanism). Moreover, we are still less aware of the impact of church schools of that period. A principal change of the paradigm in the image of Andrej Hlinka created for the young generation (after a typical boom of interim period of the First Slovak Republic) took place only after 1948 (and lasted until 1989). The analysis of texts in the textbooks of the related subjects should be included in the research of history textbooks; however, even now we can notice typical features of the displacement even elimination of Hlinka's personality from curricula, as well as its methodologically and didactically incorrect form (the use of Hlinka's Slovak National Party without explanation of the notion "A.H." etc.). It is still questionable to what extent this image, similarly as in historiography, has been formed besides ideological factors by the weakness of the Slovak methodology of history. Another even more serious question is a sufficiently verified analysis of Andrej Hlinka's popularity which is apparent among young generations of the period before and after revolution having minimum information about his personality acquired from official (formal) education.

\section{KEYWORDS:}


All the questions about a possible scope of difference between the official formation of the (national) symbol for the respective community, its officially desired changes and forms of the spontaneous collective, and individual memory of the community arise very specifically when assessing the impact of the complicated development of history teaching on the development of the portrayal of Andrej Hlinka within Slovak society. Although a more detailed research of Slovak historiography to this end is just beging launched, we dare claim that the form of spontaneously retained "memories" of Hlinka showed a surprisingly constant resemblance since the beginning up to the (actual) end of the whole period of the Slovak society's coexistence with his personality. The symbol of "the father of the nation" remained a prevailing trait of the figure of Hlinka within the general public also in the years after the political changes in 1989, which brought about a flood of new information, details about his political and social activities including many less positive facts, effectively and purposefully concealed already at the time of Hlinka's activity. There is no doubt that the enforcement of Noraesque real mission of history: to destroy and suppress memory acquired a strange form in Slovak curricula (although its motives probably do not fully correspond with Nora's real explanation of or reflection on the changing role of history). And, when considering the results of its Slovak application, we can oscillate between two extreme positions: seeing a par-excellence similarity in them as well as being astonished by the clumsy methods which should have led either to the desired results or to the form, as Nora said, of the vulgate of lofty erudition. In our paper, we attempt an initial analysis of individual manifestations on which the tradition of excusing the future in our school environment was founded. We follow the forms of the desired historical consciousness and historical memory of Slovak students built on the example of the symbol of Andrej Hlinka at all essential stages of the whole process.

Among five to six permanent top figures of Slovak (not only modern) national history or, respectively, the figures which the Slovak historical research places among the most influential, regardless of the opinions of individual authors on their roles, and among those who had and have similar approval ratings in the public opinion of Slovaks, the figure of Andrej Hlinka has been dominating almost continuously, to a certain extent, until now. At the time of Hlinka's activity and in the period immediately after his death, his high popularity within Slovak society was partially disrupted and limited by a different official assessment of his activity by the political

1 Nora, Pierre, "Mezi pamètí a historií: problematika míst". Cahiers du CEFRES. N 10, Antologie francouzských společenských věd : Město (ed. Françoise Mayer, Alban Bensa, Václav Hubinger). Mis en ligne en / published on : juin 2010 / June 2010 http://www.cefres.cz/pdf/c10/nora_1996_mezi_pameti_historii.pdf, p. 43, 45. 
and social circles representing the period Czechoslovak state, including part of the Slovak political representation, and also by a different remembrance of his individual activities within two separated significant religious communities of Slovak Christians; his popularity spread in reverse order in the war-time Slovak State. It seems that in the subsequent long phase (or phases) of official "silence" about Hlinka almost all the above-mentioned factors jointly created a certain contradictory effect - which is, however, worth mentioning in particular when assessing the results of the formation of educational portrayal of Andrej Hlinka. The results of the official "non-remembrance" policy during the whole period from 1945 (or possibly from 1948) to 1989 eventually seem as if they had not touched the national hero formation process. The first data about the attitudes of the Slovak society and its youth towards the representatives of their own past after a change of the political situation indicate, although very modestly, that Hlinka's name remained a symbol for them too, while the standpoints with confessional background seemed to have vanished. Both the "dispute" or dispute about Andrej Hlinka and the strict elimination of his personage from the national memory through historical narration seem to have failed to play the desired role, which can be hardly ascertained to such extent with respect to other symbolic names or events of the Slovak past. ${ }^{2}$

Andrej Hlinka appeared in the first Slovak - then Czechoslovak Slovak - history textbooks (more exactly: provisional handbooks for the first part of the 1920s adumbrating the birth of more or less professional texts on history) as a living contemporary renewing his political career in the period. Already the first handbooks of history amd civics, which reacted to the political and social changes after 1918,

2 We derive from the following data: Krivý, Vladimír: Kolektívne identity na súčasnom Slovensku. Pramenná publikácia dát zo sociologického prieskumu [Collective identities in contemporary Slovakia. The source publication of data of sociological research]. Bratislava: Sociologický ústav SAV, Etnologický ústav SAV 2004, p. 21-23, 53-54. (When interpreting data we also take into consideration the fact recorded by this statistics, i.e., that Slovaks belong to the societies which spoke very little about history) (Ibid. p.44).

Seemingly lower ratings of Hlinka (in comparison with Štúr, Štúr's supporters, Dubček, Jánošík, etc.) should be interpreted, in our opinion, taking into consideration the attention devoted or, respectively, not devoted to individual personages in propaganda and education during almost half a century. Štúr's supporters or Jánošík and others, in contrast to Hlinka, appeared constantly in both connections.

It is worth mentioning that one of the first studies exploring the factors of electoral behaviour of Slovak population immediately after the political change in 1989 analysed as one of its significant factors also a certain spontaneous (and different) historical memory of the citizens of various Slovak regions and pointed out a strong influence of the memories of the party represented by Hlinka during his lifetime (and which included his name into its party name after his death); Krivý, Vladimír -Feglová, Viera -Balko, Daniel: Slovensko a jeho regióny: sociokultúrne súvislosti volebného správania. Bratislava 1996, 415 pp.

Regarding the youth attitudes: Rogul'ová, Jaroslava - Valachová, Denisa: “Dejiny očami gymnazistov, Nová história 2001, Roč.1, č.3; Rogul'ová, Jaroslava: “Dejiny a patriotizmus mladých Slovákov”, Nová história 2001, roč.1, č.4, p.35; Valachová, Denisa - Rogulová, Jaroslava: “Čo o sebe vieme? Dejiny očami menšiny a väčšiny”. História, 2003, roč.3, p. 26-27. 
devoted special attention to him by the sheer size of the text. (We also dare anticipate they also predetermined in many aspects the way in which Hlinka was depicted for the young generation in the textbooks of the interwar Czechoslovakia and in a certain way in the textbooks of the after-war communist Czechoslovak state as well.) They are most aptly represented by the Slovak translation of the Czech history textbook: the Illustrated History of the Czechoslovak nation by František Hrnčír and Antonín Macht of $1924^{3}$ and the text for "people's history and geography", Czechoslovak people's history by another Czech author František Kulhánek of 1922. Their extensive passages contain high praise and even dramatic characterisation of Hlinka's activity until 1918 in the parts speaking about the last years of the Czechoslovak thrall and oppression of Czechoslovaks 5 . (Of course, what they have in mind are the conditions of the closing years of the Slovak and Czech existence within the Austro-Hungarian monarchy.) Within, the personage of Hlinka crystallised into a major representative of the Slovak national movement including all his typical positives, limits, and nuances; however, they adopt a strongly different attitude (with equally dramatic stylistics) towards his activity after 1918. Andrej Hlinka, who was already a popular Catholic priest in the Slovak milieu in the first years of the 20th century, was rooted in the consciousness of both the Slovak and non-Slovak population in particular by the spectacular events of 27October 1907 in Černová. The manner in which the authorities addressed the unrest of the local citizens in the course of consecration of the Catholic church in Hlinka's hometown spread even abroad - after all, as is well known, the whole case became one of the stimuli awakening Seton-Watson's interest in the Slovak issue ${ }^{6}-$ both the textbooks of Hrnčír-Macht and Kulhánek very emotionally describe and emphasize the drastic nature of the intervention and equally highlight the quality of the unyielding

3 František Hrnčír - Antonín Macht: Slovenské obrázkové dejiny národa československého [Slovak Illustrated History of the Czechoslovak nation]. Nakladatelství J. Svátek, Praha:1924 (Svátkova Slovenská ilustrovaná knižnica slobodného Slovenska - Svátek's Slovak Illustrated Library of Independent Slovakia, roč.1. zv.1). With regard to the Slovak translation of the Czech original we note a triviality which nevertheless unintentionally emphasizes all the upcoming problems of the teaching of history of the "Czechoslovak nation" which, after all, concerned the evaluation and perception of A. Hlinka as well: the translation was to be really consistent and so, in contrast to the original, not only the title of the work was partially changed (as mentioned in the original: Illustrated history of the Czechoslovak nation) but also the name of the author was Slovakized: Hrnčír - Hrnčír)..

4 František Kulhánek: L'udové dejiny československé. I. čiastka l’udovej vlastivedy [Czechoslovak People’s History. I Section of national history and geography] I. vydanie Banská Bystrica : 1920, II.doplnené vydanie Zemského učitel'ského spolku na Slovensku. Banská Bystrica : 1922, p. 896. Both editions were published as a manuscript present for the establishment of the so-called "Teacher Orphan Fund" at the Banská Bystrica teacher training institution (prep school of the qualified teachers for the town schools for ages 11-15) where the author worked as a teacher. Slovenský biografický slovník. III. zväzok K - L. Martin : 1989, p. 304.

5 František Hrnčír- Antonín Macht, p. 338-339.

6 Seton-Watson, Robert Wiliam: “Nábožensko-cirkevný problem”. Lidové noviny, roč. 32, 27. 1. 1924, č. 49, p. 2. Compare also: Seton-Watson, Robert Wiliam (ed) : Slovakia then and now., A political Survey. London-Prague 1931, p. 5-63, p. 26. 
personality of the rebellious priest enjoying widespread popularity among the rural population. 'Kulhánek's text, which was also certainly determined by the author's role in these events, accentuated almost in parallel and equally vehemently that a similar procedure had been applied in the educating of the Slovak adolescent generation: its alleged aim was "to trample and kill which means to batter to death everything non-Hungarian." The description of brutality of the intervention is followed by an extensive text focused on the methods of deliberate elimination of "national education (civics), geography, history, civil rights" - the practice of introducing Hungarian as the compulsory language of instruction and making the state supervision over the church schools stricter in the last decades of the Hungarian governmental regime. ${ }^{9}$

It is not only in these passages the style of both textbooks makes an impression of a journalistic text rather than an explanatory textbook. (“... It was in particular the Spiš bishop ..., who demonstrated such hatred for Slovak priests and for Slovaks in general that nothing in history can compare with it ... But also the Rožňava bishop ... was such a boor that ...” ${ }^{\prime 0}$ ). Of course, a certain portion of dramatic character should be perceived, taking into account the coeval tone of in fact all (Czecho)Slovak textbooks of the humanities. Pathos (in contrast to relatively more realistic and didactically more rational introductions) is typical in particular of the conclusions of both textbooks (and others), which are understood as the fulfilment of the "prophecy, i.e., prediction of Ján Amos Komenský" ${ }^{\prime \prime}$; especially the parts dedicated to the descriptions of the figure of Hlinka try to be as suggestive as possible. They describe his influence at that time as the influence of a priest in whose absence people even stopped going to church. ${ }^{12}$

Other passages had an even more important goal: "The current minister Dr. Milan Hodža brought charges with respect to these events in Parliament but the Hungarians shouted at him and scolded him saying that Slovaks themselves were the murders of the Černov victims. One of the deputies declared that the Parliament could not waste time on such trivialities. The minister of interior heartlessly distorted the matter boldly claiming that priests had come to calm down the people and inform them that the church would not be consecrated. The parliament accepted his speech enthusiastically ready not to speak anymore about Hlinkas, Šrobárs and Hodžas but grab them by the throat so that a Hungarian remained the master in Slovakia." The victims of the

\footnotetext{
7 František Hrnčír - Antonín Macht; František Kulhánek, p.680-682, 687.

8 František Kulhánek, p.679.

9 František Kulhánek, p. 684-687.

10 František Kulhánek, p. p. 679.

11 František Kulhánek, p. 881.

12 František Hrnčír - Antonín Macht, p. 338.
} 
shooting and victims of imprisonment are described in a similar style while almost in parallel it is reminded that "it was not different in elections either." ${ }^{\text {"3 }}$

As regards the way of conscious and systemic creation of the collective memory, we are interested also in the effectiveness, the effect of individual pressure factors; however, the last two extracts from the textbooks emerging in the new Slovak conditions indirectly answer, in a certain sense, the question how Andrej Hlinka could have impressed himself noticeably on the mind of the Slovak public even without textbook texts and in the period of not very favourable conditions: the roots of his popularity originated in the steps he took to make the degrading situation of his own ethnic group visible (or, respectively, in the circumstances which made his steps so visible). It is particularly his activity which comes out of the hard Slovak situation as a successful and widely popularized portrayal: Andrej Hlinka became one of the few bright and easy to remember points in the Slovak identity, while the connection of his clerical function with national activities, emphasized by textbooks as well, appeared to be the factor which complementarily increased his good reputation. Otherwise, at the time of the formation of the Czechoslovak state we could speak about historical "unconsciousness", forgetting, or unawareness of their own history rather than about historical memory, at least in contrast to the Czech part of the state (or its other nationalities, i.e. Czech, German, and Hungarian, respectively). Andrej Hlinka was gradually becoming one of the few bright sides of the Slovak identity which could be remembered. It was only beneficial for a purposeful representation of the new doctrine that this part of Hlinka's activities was connected with the Czech environment, as textbooks did not forget to highlight this properly.

It might be unnecessary to remind that the first "Slovakizing" history textbooks were brought into Slovak school environment along with the beginning of its radical transformation. We remind of it, however, to make clear that the textbooks we present were often used in the conditions of the Slovak interwar school system also out of their primary purpose, i.e., not only in the classes they had been initially designed for. The transformation was certainly more than inevitable, whereas at the time of the formation of Czechoslovakia the Slovak school system was in disastrous situation in every aspect, starting from the general level of the Hungarian school system, which apart from some exceptions did not reach the level of the schools of the Austrian part of the monarchy, to the literacy level of the Slovak population, material equipment of Hungarian schools, to the damages caused by the after-war chaos; after all, the Slovak education system was under the threat of collapse even during the first years

13 Kulhánek František, p. 881, 682. 
of peace..$^{14}$ Historians have been arguing about the social and political consequences of the decisions how to restructure this system (Slovakization of the system versus its unification with the system and traditions existing in the Czech lands), but the most heated disputes involve in particular the ways of Slovakization of the teaching of humanities (history and civics, religion, geography). ${ }^{15}$ The turbulent atmosphere and ambience of those days, prevalent among the teachers of primary (public) schools, was only escalated by the chaos arising from inappropriate understanding of the attempts at new concepts for the content of traditional subjects as well (apparent, for an instance, from the disputes about the curricula of national history and geography, i.e., basic subjects of public schools, where history was one of the essential components), so "the Slovak teaching staff which had by then observed Hungarian laws was caught in a big uncertainty and helplessness and had to rely only on its own abilities acquired in Hungarian teachers training institutions and on their shorter or longer teaching experience." The majority of teachers saw new curricula as unnecessarily narrowed and "could not understand why a Slovak child was not allowed to have the sciences too, taught by then within the history of "basic science" [natural history, physics, chemistry], and which were marked in Hungarian curriculum as special subjects, ... the curriculum issued was considered by everybody as a "dilettante" attempt of the school nobility..." this is how the interested contemporary witness ended his description of the situation. "This general opinion was frequently demonstrated in a caustic manner..." ${ }^{\cdots / 6}$ In other words, the interwar education in Slovakia could have been built with slight or at least without greater methodological difficulties: "it could have used the fundament of Magyar Allami Népiskoly or Kegyesrendi gimnázia in maths, physics, German or Latin languages" as aptly noted by one outstanding Slovak historian, but we confirm that "the teachers of the 'Czechoslovak language' in its Slovak version and teachers of history were in a different situation” (we can add civics and the humanities here as well). ${ }^{17}$

Therefore, if we are trying to find an answer to the question to what extent the new textbook texts could have effectively influenced the formation of a desired new consciousness of the Slovak community - taking into consideration the well-known

14 In detail: Kázmerová, Lubica: "Vznik a rozvoj slovenského školstva” [The formation and development of the Slovak educational system], In Slovensko v medzivojnovom Československu. Bratislava : 2012, p. 154-166.

15 For more details on the issues concerning the teaching of history and civics see: Tonková, Mária: "Civics and Civic Education in the Slovak Republic - its Tradition and Current Situation and Model in Relation to History". Prace Historyczne: Zeszyty Naukowe Uniwesytetu Jagiellońskiego .142 (/2) , p. 219-242.

16 Nedbálek, L'.: "Pojem vyučovania vlastivedy ako predmetu ludovej školy" [The concept of the teaching of national history and geography as a subject in public schools]. Národná škola. I/1923, p. 268-269.

17 Lipták, Lubomír: Storočie dlhšie ako sto rokov [The century longer than a hundred years]. Bratislava:1999, p. 148. 
fact that they wanted to build it as Czechoslovak - we must admit that at least in the above-mentioned parts - where Hlinka is presented both as a popular religious representative and patriot exposing the priest post to risk in favour of his nation ${ }^{18}$ - both textbooks "hit the nail on the head".

The interwar textbooks for junior classes of primary schools failed for purely practical reasons (like the textbooks of the era after the Second World War in other contexts, after all) - they could not utilize the potential of the figure of Hlinka to such extent or so successfully as to underline his pro-Slovak activity in line with its effective and desired inclusion into the needs of the emerging state, into the thoughts requiring the building of the concept of the united nation but, at the same time, including the republican ideas of its members as well. Other contexts also played a certain role. In the History of the Czechoslovak Nation - History for Slovak Public Schools written by another productive author of Slovak textbooks (not only the history textbooks but also civics and other subjects) Jozef Koren ${ }^{19}$, there is no text directly mentioning Hlinka. Instead, $\mathrm{it}^{20}$ tried to form the consciousness of pupils in the same spirit as the already mentioned textbooks. The process of the modern Slovak and Czech national emancipation is characterized in Chapter 19 as the revival of the Czechoslovak nation (of course, the first and second Slovak revival and the Czech revival are analysed in more detail). The Slovak and Czech events of 1848 are characterized as Czechoslovak resistance (although again admitting different characteristics of the Czech uprising and the Slovak uprising). The strictly condemning vocabulary which in Chapter 21 describes the course of Magyarization does not, however, lapse into a tabloid tone ${ }^{21}$ (it even specifies several facts which add some "grey" or even "multi-perspective" accents ${ }^{22}$, as defined by the contemporary educational terms, to a clearly cut black-and-white picture. It does not deny the tragic nature of the Černová events, briefly stating, however, that they happened because "the brave Černová citizens did not want to allow

\footnotetext{
18 Hrnčír František - Macht Antonín, p. 338.

19 Encyklopédia Slovenska : III. zväzok. K-M. - Bratislava : Veda, 1979, p. 166.

20 Koreň, Jozef: Dejiny československého národa .Dejepis pre slovenské ludové školy a pre opakovacie školy. Nákladom Štehrovho kníhkupectva, 63s, Prešov : 1922.

21 Koreň, Jozef: Dejiny československého národa.Dejepis pre slovenskéludové školy a pre opakovacie školy. Nákladom Štehrovho kníhkupectva, 63s, Prešov : 1922, p.41, 42, 45, 50-55.

22 For an instance, besides a more realistic and positive evaluation of the Hungarian anti-Habsburg uprisings, the textbook evaluated F. Deák as a „brave man“ because he pushed forward the National Law in the Parliament in 1868. (On the other hand, it did not forget the burning of books by the outraged [Catholic] priests at the time of reCatholicism in the Czech lands. Ibid, p.52, 36. The evaluations of F. Deák correspond with the longer lasting viewpoints of history texts of the Slovak evangelical church schools. Compare, e.g.: Školník pre školy evanjelické augsburského vyznania (coll.) Vydal Nitriansky seniorát, II. vydanie, Senica 1906, čast': Ústavoveda (A .P. Záturecký), p. 141.
} 
their new church to be consecrated by the priest who did not stand up for the Slovak people" (not indicating the name of Hlinka). ${ }^{23}$

A seemingly only slightly different manner of providing information about the same essential issue, and possibly the best known event of modern Slovak history, reveals the first internal dilemmas which were addressed by the creators, ideologists, politicians and textbooks authors after 1918 shaping the desired new collective memory and seeking adequate symbols for the building of a coherent national community among the adolescent part of the Slovak community. Apparently, however, at the same time they also partially revealed the broader period atmosphere in which the new Slovak concepts of their own past were strengthened. It is obvious that the portrayal of Andrej Hlinka became not only a popular but also a desired icon mainly within the Slovak Catholic environment; it seems surprising that this wave - and part of Hlinka's activities - was utilized in particular in the textbooks whose creators did not directly solve many emotional dilemmas in connection with religious confession. Already the first teaching texts of the Slovak evangelical church schools which appeared in the new conditions (and certainly also the teaching at these schools itself) indicate, however, at least a more aloof relation of this environment to the personage of Hlinka. If we add to these facts the changing role of Andrej Hlinka in the after-war Czechoslovak Slovak society, further dimensions of the newly built (institutional) memory of Slovaks and simultaneously growing possible differences between this memory and the spontaneous memory of individual strata of the community and its members will open before us.

It is rather amusing that in no interwar textbook we will find a reference to possibly the best known statement of Hlinka, by which he expressed his attitude towards the emerging Czechoslovak state in the key moments when the domestic Slovak political representation made decisions (the Slovak environment and history textbooks give the almost chronically well-known slogan about the unsuccessful thousand-year marriage with the Hungariansm which therefore had to split up). Can we admit that the omission of Hlinka's decisive standpoint expressed in the course of adoption of the so-called Declaration of the Slovak National Council of 30 October 1918 from the teaching texts compares with the "non-mentioning" of the controversial steps of the popular personage at the Paris negotiations regulating the international legitimacy of new states in the same textbooks? Anyway, this also adumbrates another part of the formation of the attitudes of adolescents towards Hlinka through the teaching texts in the simplest manner: by silence.

23 Školník pre školy evanjelické augsburského vyznania (coll.) Vydal Nitriansky seniorát, II. vydanie, Senica 1906, čast: Ústavoveda (A.P. Záturecký), p. 54. 
The renewed political career of Andrej Hlinka from the period of the first editions of new history handbooks and textbooks (i. e., following the consequences of his activities at the Paris peace talks) already mentioned at the beginning of our analysis actually also meant still greater contradictions of the autonomist politician establishing himself in the state doctrine of a new state. It is, however, difficult to state more exactly in a few lines whether it was the centralism of the doctrine (and the idea of the united Czechoslovak nation) which played a more significant role in these contradictions, or it was rather its secular republicanism (or even the form of Catholicism of the Czech environment which was too liberal for Hlinka). The interwar political activities of the personality, who was becoming increasingly controversial for the state, as well as previously highly accentuated references to Hlinka's role in tying close relations between Slovaks and Czechs, more or less disappeared from the textbook pages. The above-mentioned textbook of Hrnčír - Macht prepared a certain "explanatory" background which, in the beginnings of new parts of the text, i.e., at the time of the first Czechoslovak Republic, characterized Hlinka very briefly and definitely as the leader of the Slovak People's Party "with antinational and anti-state programme", claiming that "jail has changed Hlinka" and interpreting with regret his altered positions ("he became alienated from the nation") as a result of his reconciliation with the bishop. ${ }^{24}$ In particular, the intentional disregard for the figure of Hlinka is very striking in the texts directly emphasising the growing activeness of the Slovak national-political movement and just in a simple comparison of the quantitative representation of other much less significant contemporary Slovak personalities or politicians. Of course, we can admit "non-malicious" reasons for omitting the figure of Hlinka as well: the respective proportion of a predefined and mostly very limited volume of the text devoted to individual events, trends, personalities is determined by unconcealed, clearly admitted criteria with the period republican orientation of the humanities teaching of the time. Just at a glance, however, we will find many names of politicians as examples of "national heroes" whose significance is simply immeasurable compared with the significance of A. Hlinka.

Regarding the current level of research, we can only deduce how the concepts presented affected their "consumers" both in the first and second decades of the twenty-year interwar period. It is obvious, however, that the generations of young people were gradually formed, raised, and educated in Czechoslovak schools, so that they bore still less "Hungarian heritage", but the development of their consciousness lay new contradictions before them. The growing popularity of Andrej Hlinka

24 Hrnčír František - Macht Antonín, p. 338. 
among a major part of the Slovak population was becoming an increasingly striking and undeniable fact regardless of the extent to which it was created by more or less smart propaganda of his own party and by the populist traits of Hlinka's policy. Naturally, the same facts included the heated disputes of contemporaries about the personality and traits of Hlinka too, which was admitted and reminded not only by the outstanding contemporary witnesses but also directly by Hlinka's ideological colleagues. ${ }^{25}$ However, all of this did not change the fact that while the members of the People's Party were ostensibly taking the initiative in solving the so-called Slovak issue in Czechoslovakia, Hlinka was definitely "transformed" into a symbolic "father of the nation" in the mid-1930s.

It is therefore clear that the teaching texts presented by us in such comparison corresponded with the predominant social atmosphere even less. Unfortunately, this also applies to a possibly most refined form of a textbook text which was made available to Slovak students during the interwar period: the secondary-school textbook of Czechoslovak history written by the respected Czech historian Jozef Pekař (primarily designated for the senior classes of the secondary level of education). It was introduced into the programmes of history curricula by school regulations as soon as in 1921, including the programmes for Slovak schools, used virtually throughout the whole twenty-year period, and published in a partially revised and shortened version in $1937 .{ }^{26}$

We are convinced that the extraordinary quality of the textbook by Pekař cannot be called into question even today, even though the voices of teachers about its complexity led to the revised edition, which was published towards the end of the Czechoslovak Republic with the contribution of another well-known historian and

25 We have selected but several typical evaluations by eminent personages of Slovak journalism, the public, and Hlinka's contemporaries: "Wherever this fighting man went it was snowing heavily, a storm was raging and the rain was sheeting down. Many people blamed him for that, called him a rebel but today we definitely know that we needed a man just like him. A fascinating preacher man, rebel and fanatic of the Slovak truth had to come, a spontaneous human hurricane free of sentimentality and considerateness had to come to stir up the dead Slovak lake up to the bottom." (Milo Urban, writer, 1938) In: Letz, Róbert: Andrej Hlinka vo svetle dokumentov [Andrej Hlinka in the light of documents],. Bratislava: 2014, p. 258.

"Hlinka.... he knows how to take the people by storm to festive peace but also to a fervent rage. It will be an unforgettable experience for the one who saw Hlinka making a speech before the crowds of thousands people. It was not so important what he said, important was that it was said by Hlinka and the impression was incomparable... he is a deeply suggestive personality." (František Skyčák, philospher, Catholic priest, 1934); "Some love him blindly and the others hate him equally blindly. There is something divine in him! - some would say. And they want him to be worshiped. - There is something diabolic in him! - others would say, and they would like to destroy him.” Jur KozaMatejov, novinár, r. 1925.[Emphasis by M.T.-A.B.] http://www.andrejhlinka.sk/povedali-o-hlinkovi/.

26 Pekař Josef: Dějiny československé pro nejvyšši třídy škol středních. Nákladem Historického klubu v Praze Klementinum: 1921, 198 p. Pekař, Josef - Klik, Josef : Dějiny československé pro nejvyšší tř́idy škol středních. 2. podst. zm. a skr. vyd. Historický klub, Praha: 1937. 174 pp. 
textbook text author Josef Klik. ${ }^{27}$ It was due to the high professional level of the original textbook, highlighted by the above-mentioned paper at the Congress of Czechoslovak Historians, which claimed that any praise for its values would be useless unless its fundamental problem is pointed out. ${ }^{28}$ The similar reproach of the Czech historian for its "Bohemian centrism" 29 overlooked, on the contrary, another noticeable moment. The explanatory text of Pekař can be considered as oscillating within the existing national and political framework but it does not attempt at an unnatural construct of the Czechoslovak nation where it does not exist. He perceives the possibility of different narratives of the communities living in the interwar Czechoslovak state. His references to Slovaks, their formation, existence, cultural life, and territory from Early Middle Ages to the 20th century are organically incorporated into the Hungarian context too, properly and without unnecessary dramatization and pathos, so that a contemporary reader may realise another strong point of the whole explanatory text: a concentrated attention devoted not only to political or possibly cultural history but also to economic and social history; even the graphic layout is close to the present criteria for textbook texts (e.g., shorter subheadings which characterise individual parts of each of eight chapters on the side bars of respective pages).$^{30}$ The second version of the textbook adapted by Klik and translated into the Slovak language, which took into consideration all the aforementioned reproaches (i.e., had a more extensive Slovak context), was released too late to take root in the broader educational context of the Slovak environment. ${ }^{31}$ The first long-term used version of the textbook, however, devotes only less than a half page to the Slovak situation in the last decades of the 19th century or, respectively, in the first pre-war decade of the 20th century, i.e., a general description of the well-known Magyarization. The name of Andrej Hlinka did not thus appear in the textbook and, consequently, any reference to the famous Černová either. ${ }^{32}$ In the Slovak translation of the publication of 1938, the qualities of the original text are even more apparent, thus the Slovak reproaches to it can be repeated from the same point of view.

27 Flegl, Michal: Historik Josef Klik. Nad knihou Bohumila Jirouška. In: Rodopisná revue on-line, 25, roč.15, č.1, 2013. http://rodopisna-revue-online.tode.cz/2013-1/25-27_flegl-klik.pdf, p. 26.

28 Šikura, Ján, Učebnice dějepisu. In: Prvni sjezd československých historiků 1937. Praha : 1938, p. 273.

29 Němec, Mirek: Škola mezi národem a státem. Dějepis na středních školách v medziválečném Československu. In: Historia scholastica I, sv.1, Praha: 2013, p. 52.

30 Pekař Josef, 1921.

31 Pekař Josef : Dejiny československé pre najvyššiu triedu stredných škôl. Spracoval Josef Klik, poslovenčil Cyril Chorvát. Praha: 1938.

32 "Doba císaře Františka Josefa: Poslední čtyři desetiletí před válkou" [The era of the emperor Francis Josef: The last four decades before war] (Kap.VII/6) In: Josef PEKǍ̌, 1921, p.153-157, p. 156. 
Let us remind, however, that the form of curricula in the first Czechoslovak Republic substantially differed from the current curricula: they provided much more authority both to the school and individual teachers to fill in the expected chronological context of the teaching by their own content. ${ }^{33}$ In other words, when assessing the formation of a "systemized" memory of the young generation of the interwar Czechoslovakia, we should take into consideration a much broader context, have in mind the influence of the external environment and also the fact that, compared to the subsequent war and after-war period, it could have a more spontaneous and free effect. A number of other factors certainly and quite naturally affected a concrete form of the teaching. One of them could have been the process in which the Slovak teachers managed, in particular in the period of the first republic, to address the deficits caused by the restrictive Hungarian education system and its school policy. The Slovak collective picture of the past perceived in a more different way appeared and its promotion started first in Slovak texts for junior classes, but in the 1930s voices were already heard from Slovakia which formulated more comprehensively the whole basic problem of history education in the multinational state: the method of inclusion of various national perspectives into an integrated explanatory text. It was not until the end of 1930s, exactly at the first Congress of Czechoslovak Historians (1937), where in connection with the discussion of the didactic section on the textbook by Czech historian Jozef Pekař used for the whole two decades for teaching in the senior classes of Czechoslovak secondary schools (in Slovakia even until 1938 in the Czech version) it was unequivocally declared why Slovak teachers wanted more Hungarian and Slovak issues in the teaching (Hungarian history as far as it took place in Slovak regions), why just supplements to Slovak life and institutions in the "Slovak-made" textbooks would not help in the creating and building of the united state organism, education towards the "conscious Czechoslovak patriotism", so the requirements for the method by which a really integrated synthesis of Czechoslovak history should be created - if a political Czechoslovak nation was to be built. ${ }^{34}$

The years of the first Slovak republic naturally were a fundamental milestone for a change of textbooks' attitude towards Andrej Hlinka. Besides turbulent circumstances of the Second World War, they are by coincidence also the first months, or years, after Hlinka's death. Therefore, in this case, the "second" life after death of the hero officially acquired also new contours very quickly. The most typical and, because of

33 Tonková, Mária: “Civics...”.

34 Šikura, Ján : Učebnice dějepisu., p. 271-273. The Slovak representative requested as a natural procedure for the real synthesis of common history also a real mutual learning of the history of the counterpart - incorporation of the Slovak history into the Czech history, not just the common reverse order. 
a limited possibility to use other materials at that time, also almost the only example is represented by the history textbook written by the best known Slovak historian of that period František Hrušovský, respectively the simplified versions of his historical work of the same title Slovak History in the prescribed variants for history teaching at both primary (public) and secondary schools. ${ }^{35}$

The substance of a compulsory shift in the perception of the personality of Andrej Hlinka can be briefly described by the words of the author himself: "the situation has changed, people have also changed ... only Andrej Hlinka has not changed..." A sharp change in the evaluation was visibly mirrored also in the extensiveness of the text, i.e. in the extensive space given to the figure of Andrej Hlinka on the pages of both textbooks after the previous twenty-year period of omitting him more or less deliberately. A question, or rather a thesis, which needs to be verified more precisely, consists of the aforementioned fact of the transmission, retention of these interpretations in the contemporary consciousness or respectively current historical culture of adolescents in Slovakia: To what extent do the previous Hrušovsky's evaluations of the personality of Hlinka correspond with opinions, ideas and emotions of the contemporary generation of young Slovaks? What other factors of the then social atmosphere jointly affected our so far functioning Hlinkaesque model "topoi"?

František Hrušovský is one of the most significant but, at the same time, one of the most contradictory personages for a contemporary Slovak historian when analysing national historiography after decades of its rigid development and assessment. In connection with our topic, we should at least mention his controversial approach to the question of how to describe history of the nation without its own state. Both versions of his textbook naturally repeat the theses expressed by him in his attempt at a popularizing synthesis of Slovak history: in his concept he attached little importance for instance to the development of reformation in Slovakia; he values more the role of the Catholic than non-Catholic Slovak representation for the development of national and cultural emancipation of Slovaks; in his work his interest is focused mainly on the last decades of the national development, the explanation of which he narrowed down to the activities of the People's Party. ${ }^{37}$

The figure of the leader of the Slovak People's Party thus naturally became the central point of the presentation of both textbooks, presented with equal bias and in

35 Hrušovský František: Slovenské dejiny. Učebnica pre IV. triedu slovenských stredných škôl. Turčiansky Sv. Martin, Matica slovenská : 1940, 208 p.; Dunaj: dejepis pre 6. postupný ročník slovenských ludových škôl Trnava, Spolok sv. Vojtecha: 1939, 100 p; Dunaj: učebnica dejepisu pre slovenské ludové školy1941, 2. opr. vydanie, Trnava, Spolok sv. Vojtecha : 1941, 100 p.

36 Hrušovský František: Slovenské dejiny. Učebnica pre 4. triedu slovenských stredných škôl. Bratislava: 1944, p. 181.

37 Hrušovský, František: Slovenské dejiny. Martin, Matica slovenská : 1939 (II vydanie), 448 pp. 
the same dramatic style as in the previous textbooks, but in reverse order. In the descriptions of the beginnings of public life in Slovakia after 1918 the texts of Hrušovský shortly recognize the importance of a "helping hand" of the Czech intelligentsia arriving in Slovakia but whereas its general role, goals and behaviour is evaluated in them mostly negatively, after all they can express in emotional vocabulary that Andrej Hlinka "observed with disgust the rampage of Czech people who in the name of enlightenment and progress brought moral decline to Slovakia" and describe in the same style all Hlinka's activities against the modernisation process coming from the Czech lands. "Andrej Hlinka could not see how the Slovak nation ... was heading for disaster", therefore "he founded the press which educated Slovaks towards national self-confidence and the fulfilment of national duties but first of all he alone travelled around Slovakia to awaken pride, belief and courage in the nation at public meetings by the enthralling strength of his deep confidence." 38 The extensive texts devoted to Hlinka were supplemented in textbooks by similar extensive praising parts about the activity of Hlinka's Slovak People's Party (renamed to Hlinka's party supposedly in order to differentiate it from the "Czech" people's party (in fact the state-wide Czechoslovak People's Party); an outstanding politician of the Slovak People's Party Martin Rázus is presented only as a purported "autonomist"; Hlinka’s colleague, Milan Hodža, a politician of Central-European calibre is presented as a weak personality tacking from side to side; but the text steers into unsafe waters by its positive approach towards the member of HSL'S Vojtech Tuka, who was inclined to extremism.

A radical change of the concept, conclusions and viewpoints on history teaching could not certainly broing about equally fast radical changes in historical consciousness of the contemporary youth. However, the conditions under which the Slovak education system was formed anew played seriously into such change: plurality of the social life, professional and hobby organisations not in line with the new direction had been already liquidated in the period of a short-term autonomy, the authoritarian regime of the first Slovak Republic also established deep structural changes in the educational system designated as the "regeneration process", in which everything that according to the new ideologists did not correspond with or resisted national and Christian traditions should have been eliminated, as along with pedagogical and didactic mistakes of the previous education etc., which in fact meant tough restrictive steps considered as a desired antipole of education in the spirit of liberal democracy: new uniform curricula and textbooks, education provided at new public schools out of which almost ninety percent were changed into church schools, a single type of

38 Hrušovský, František: Slovenské dejiny. Martin, Matica slovenská : 1939 (II vydanie), p. 388.

39 Hrušovský, František: Slovenské dejiny. Martin, Matica slovenská : 1939 (II vydanie), p. 373-416. 
general secondary education, i.e. "grammar schools", up to the abolition of the coeducation system of teaching. ${ }^{40}$

The previous "disputes about Hlinka", critical attitudes of the members of nonCatholic confessions and even part of Catholic circles did not reach the public almost at all. New evaluation of the figure of Hlinka, his place in Slovak history was, however, in accord with the views and ideas of majority part of Slovak society of those days. The state policy just started nurturing the already growing cult around Andrej Hlinka. The contemporary Slovak author emphasizes that a strong wave of nationalism and the national constructive enthusiasm can partially explain a certain laxness with respect to the starting of the authoritarian regime and ending of the plurality principles on which the CSR was based. ${ }^{41}$ The textbooks of Hrušovský corresponded with all nuances of the increased national euphoria as they strongly emphasized Hlinka's interwar, supposedly central "role in the political fight against the Czechoslovak unifying efforts (and against international socialism)", the role with the help of which "the Slovak nation was awoken, educated and led to become a national unity". The assertion that Hlinka thus got into the role "that nobody in Slovak history has ever had" is just a final accord in which all emotions and memories of the former political figure sounded. ${ }^{42}$ And the young generation was influenced by various widely promoted demonstrations supporting the remembrance of merits of the "father of the nation", which were transferred to the school environment by the official support given to the cultural and sports out-of-school activities of each school, and also by the period's official press (in particular Slovák and the press body of paramilitary groupings of the People's Party Gardista) which, to build a new pantheon of Slovak national heroes, tried to form up in various ways but also "rebuild" memories of individual Slovak personages among the public. ${ }^{43}$ (The propaganda even tried to make a link between A. Hlinka and M.R. Štefánik. ${ }^{44}$ ) Many occasional poems, songs and even projects of the mass physical exercise performances devoted to the leader "of the Slovak nation"

40 Compare: Sivák Jozef: “Slovak educational system and its growth”, Slovák, roč.26, č.61, 14.3.1944, p. 19-21. Q by: Pramene k dejinám Slovenska a Slovákov XIIIa - Slováci a druhá svetová vojna. Bratislava : 2015. , p. 171-173. J. Sivák was the Minister of Education of the war Slovak Republic (1939-1944).

41 Rogul'ová, Jaroslava: “Autonómne Slovensko I.”, in: Pramene k dejinám Slovenska a Slovákov XIIIa, p. 19.

42 Hrušovský, František : Slovenské dejiny, p. 390, 391.

43 E.g.: Mederly, Karol: “Andrej Hlinka - jediná autorita prýštiaca z duše slovenského národa” [Andrej Hlinka - the only authority spouting out from the spirit of the Slovak nation], Slovák 21, č.96, 26. apríla 1939, p. 1-2.

44 [Mach, Alexander:] “Štefánik a Hlinka - jeden duch, náš duch!” [Štefánik and Hlinka - one spirit, our spirit!], Gardista, 1, č.14, 6. mája 1939, p. 12.

Compare also: Macho, Peter: M.R. “Štefánik a A. Hlinka v básnických a komemoratívnych textoch. Historická osobnost' ako národný symbol a jeho štylizácia”, Studia Academica Slovaca, 34, FFUK, Bratislava: 2005, p. 367-396. 
poured out ${ }^{45}$, which were of a very low or no artistic value but widely used for various student performances at school or other celebrations. Their expressions attempted, for instance, to present the cult of Hlinka simply as a fact according to which "the people need a kind father, as well as a strong hand, all-wise head...” Etc., repeating in a banal form all the principles of the period propaganda. ${ }^{46}$ However, such events in particular should be analysed in detail in the future - their frequency and real size, successfulness, i.e. their potential to really affect the structuring of historical memory of the young people growing up in the war Slovak Republic can be verified only by a detailed research into individual school reports.

The more imperceptibly a repeated fundamental political change of the Slovak educational system was sneaking in, the longer lasted the phase which made a substantial impression upon official perception of Andrej Hlinka in the state political doctrine and created a new hiatus at least in the institutional collective memory of Slovaks with respect to him. We naturally consider the year 1948 as a milestone of a fundamental change in the paradigm, although already during the preceding approximately threeyear period clear-cut actions were constantly taking place, which predetermined the whole character of the future formation of the historical consciousness. In the conditions immediately after the war the amendments to the existing textbooks included (first through a simple deletion of inconvenient formulations from their texts) the introduction of the working materials to the school scene which were drawn up in haste and consequently stricter; at the same time even more restrictive instructions of the Ministry of Education -and later on of the party bodies - to experts how they should present the Slovak past. A clearly one-sided period of more than a half-century along with the obviously unilateral type of socialization of adolescents, including the formation of their "memories" of the past, were so long and monotonous in the strict sense of the word also because the humanities school subjects were unable to capture for them the too short signs of changes in the evaluation of the past which appeared in the social and political atmosphere in the mid-1960s or in the second half of the 1980s. In connection with our topic, however, the situation appears to be especially bizarre. Historical aspects of coexistence of the Slovaks and Czechs and with regard to them also the opening of the question of Hlinka's role in the Slovak (Czechoslovak) history created, after all, one of the most typical characteristics of

45 Andrej Hlinka - vodca slovenského národa [Andrej Hlinka - the leader of the Slovak nation] . vol.II: Drama and drama songs. Trnava, Fr. Urbánek: 1938, 54 pp.; III. zv: Symbolické prostné na národné piesne, Dramatizácie, symbolické, rojové a skupinové cvičenia [vol III.: Symbolical floor exercises to folk songs, dramatisation, symbolical, cluster and group exercises]. (Uporiadal Andrej Zemančík. Trnava). ,Fr.Urbánek: 1938, 78 pp.

46 Andrej Hlinka - vodca slovenského národa, I., p. 62. 
the first wider and more open discussions of Slovak society in both periods. ${ }^{47}$ In the second half of the 1980s the figure of Hlinka (along with the question of evaluation of the president of the first Slovak Republic Jozef Tiso and a general opinion on the war Slovak Republic) became one of the hotspots of the discussion. It was manifested as an apparent historical party politics which confirmed latently persisting conflicts not only between the ruling and emerging opposition circles but also between the Slovak and Czech parts of the domestic and exile opposition. ${ }^{48}$ The Czech author, who in his synthesis of the development of the Slovak-Czech relations captures also the influence of the functionality of historical consciousness and historical memory of both these nations on a concrete course of the most important turning points in history of the Czechoslovak state, believes that, if appropriately grasped, these themes in particular could in a certain way strengthen the awareness of the common (i.e. Czechoslovak) destiny. $^{49}$ (Our insufficiently answered question about the real influence of the educational system on the structuring of the compact and spontaneous historical memory of young people thus acquires other important contours).

We are not the supporters of the often-used interpretation that Slovak texts of Czechoslovak textbooks were only mechanical translations of Czech textbooks during the whole period of 1948-1990. Slovak authors were also represented in the groups of authors, and if we see deficits in their author contribution, it is necessary to go deeper in particular into the question to what degree they were connected with the general situation (weakness) of Slovak historiography of that period (and of Slovak textbooks authors of the time) compared with the Czech environment. On the other hand, Slovak historiography, rigidly fixed to the more developed Czech historiography (understood as Czechoslovak), could have hardly developed in a different way.

Anyway, the newly constructed narrative of the (Czechoslovak) Slovak collective memory decided already in its beginnings not to choose almost anything from the so-far fixed ideas and memories of Hlinka, which situation was maintained as an imperative during the whole above-mentioned half century in a considerably false belief that it fulfilled a brand new type of ideologization. It makes no sense to deal in detail with each history textbook used in Slovak primary schools in the period of the communist socialism, since the whole indoctrination and uniform curricula clearly manifested itself also in the production of textbooks: the Ministry of Education always approved only one textbook for a given subject for any given grade of the respective type of school, alternative forms or just any signs of them were absolutely unacceptable. The

\footnotetext{
47 Rychlík Jan: Rozpad Československa. Československé vztahy 1989-1992, Bratislava, AEP : 2002, p .44-51.

48 RychlíkJan: Rozpad Československa. Československé vztahy 1989-1992, Bratislava, AEP : 2002, p. 46-47, 48.

49 Rychlík Jan: Rozpad Československa. Československé vztahy 1989-1992, Bratislava, AEP : 2002, p. 24.
} 
formulations taken over from older textbooks regularly appeared in newer textbooks and this does not involve only headings or subheadings of chapters but it is particularly in them that the politically imposed formulas can be best seen. Therefore, a detailed description of all texts would be just repetitive. However, what after all creates new and what creates only old (and old-new) "symptoms" of the situation in which Hlinka completely disappeared from history texts and also from history teaching: should he have thus disappeared also from the memory of adolescents?

The tendency not to mention some events and personages only because they seemed ideologically and politically unacceptable to the establishment, but mainly in order to prevent the opening (we note that on both sides) of any questions of the past which might disrupt the Czecho-Slovak relationship, can be decoded in the textbook which was approved by the Slovak Commission of Education in July 1947 as a provisional teaching aid for secondary schools. The Brief History of Czechoslovakia, written by three authors, has a clear objective: a new interpretation of national history mainly since 1918 summarized in the last three, but specifically in the last two chapters of the text ("Fights of the Slovaks for national freedom and autonomy; the period of the World War, the period of the Second World War"). ${ }^{50}$ In the political situation of the near ultimate assumption of the power by the Communists, the textbook mentioned (had to) some facts, and left out some others. Its tone is, however, unambiguous. It briefly and properly explains the substance of the process of Magyarization, summarizes in a few points "the resistance of Slovakia against denationalization" while it considers "the orientation towards the Czechoslovak national unity" to be its most important sign. Only an experienced reader will be able to identify from the text the role of Andrej Hlinka in this period - but it might be just a secondary-school student with recent memories of his childhood: one of the points of the previously mentioned resistance against Magyarization actually speaks about the protests against the "imprisonment of Slovak patriots" in 1906. However, there is not a word about the Černová events. ${ }^{51}$ Hlinka's name appeared in the textbook only once and in a very brief context: the still highly evaluated development of the interwar Czechoslovak Republic, or similarly as a harmonically assessed development of the interwar Czechoslovak Republic, the Slovak development within the Czechoslovak context of those days was according to the text "disrupted by the actions and activities of the Slovak People's Party established by A. Hlinka". The text attempts to make a link between the autonomist requirements

50 Petrenko - Hollý - Janega : Stručné dejiny Československa. II. nezmenené vydanie . Hargašove školské príručky. Bratislava :1947, 79 pp., p. 58-66, 66-74, 74-79. Authors' names are mentioned in the textbook for the first time without birth names!

51 Petrenko - Hollý - Janega : Stručné dejiny Československa. II. nezmenené vydanie . Hargašove školské príručky. Bratislava :1947, p. 65 . 
of the Party (i.e., of Hlinka) and erroneous concepts of the state development actually stating that "this Party made use of some mistakes of the political public life and was determined to implement the autonomy of Slovakia at any cost".

Starting from the 1950s up to the mid-1980s, history textbooks of Slovak (Czechoslovak) schools already intentionally repeated other explanatory models known from the interwar Czechoslovak Republic as well: although this time they strictly followed the concept of autonomy of both nations, the moments of their historical similarity are still brought into focus. ${ }^{53}$ The building of the Slovak collective identity acquired some old traits in a new guise and its most typical trait consisted of a renewed disproportion between the attention devoted to the Czech and Slovak history, already criticized by historians and teachers long ago (i.e., at the above-mentioned pre-war congress). Amajor part of the explanatory text dealing with the Slovak past was thus chronically and sometimes quite unnaturally a sort of an appendix to the history texts explaining the Czech past.

Behind the elimination of the figure of Hlinka from such model (or rather a normative) of building of historical memory of the Slovak youth growing up in the conditions of the communist Czechoslovakia we should see, however, a number of more general connections arising from the ideas of the Marxist doctrine or wellknown "rules of history" or the role of a personality in historical processes. It is clear that under the rigid conditions ruling in the state before the political change in 1989, no other ideology than the Marxist could have created an alternative interpretation, and almost all figures of the Slovak past suffered the consequences of this. There are some of them which did not disappear from the textbooks of any of the so far monitored stages (Štúr, Hurban, Hodža, Štefánik), but their portrayal has also undergone a transformation from a highly individualized and lively personage up to a "factor of the social and political development". ${ }^{44}$ The Marxist rules outlined a uniform picture in two parallel lines. The desired emphasis on impersonal "iron rules" of historical process together with the highlighting of the class aspect changed, in particular in the texts dealing with the periods covering the activities of Andrej Hlinka, into a very schematized sketch of the economic development, or rather economic situation of the lower classes of society. Just for this reason, in fact, no personage had its place in

52 Petrenko - Hollý - Janega : Stručné dejiny Československa. II. nezmenené vydanie. Hargašove školské príručky. Bratislava : 1947, p. 72.

53 Compare: Očenášová, Slávka: Schválená minulost'. Kolektivna identita v československých a slovenských učebniciach dejepisu 1918-1989. Košice: 2010., 159 pp.

54 Of course, the textbooks include a number of personages from the area of cultural development (and consequently also the functionality of their anchorage in the historical consciousness) while utilizing the period satirical term of the "phone directory" for those parts of the texts. 
them. It seems that while in the beginnings of the national emancipation there was applied a rule allowing speaking about the real, concrete deeds of historical figures, it was in fact the working class which assumed the role of the representation of Slovak society in the last decades of the 19th century, and thus its activities were emphasized. The textbook for the 8th grade of primary schools of 1962 (however, it was released in its fourth reprint in 1969 and was used also in the mid-1970s) summarized all supposedly most important characteristics of the Slovak development prior to the First World War under a symptomatic title: "Slovaks prior to the First World War and the response to the Russian revolution in Slovakia". Slovak culture which, according to this text, "played an extremely important role in the Slovak national life is seen here mainly as the culture whose representatives had a distinct relationship to the workpeople and farmers." ${ }^{35}$ The impersonal vocabulary helped to eliminate in advance all the signs which, in the period of the so-called normalization, would possibly condemn to extinction any text created in another period. However, a similar procedure and in fact similar formulations were used also in the new textbook of the mid-1970s for the same grade of primary schools, which covered the same period. Of course, there is no reference to Hlinka (and to the Slovak People's Party) in it either. ${ }^{56}$

The authors of textbooks had to choose a partially different procedure, or respectively more prevarications for the then highest grade (the 9th), whereas the curriculum prescribed to them the teaching content covering the whole modern period from the First World War up to the present time (the XIV Congress of the Communist Party of Czechoslovakia became a milestone of most textbooks of national history of the normalization period). The text of the 1971 textbook, which was several times reprinted, chose the May Mikuláš manifestation out of the 1918 events which signalled the recognition of the common state of Czechs and Slovaks by the Slovak representation mentioned there as "a significant milestone in the fight of the Slovak working class against the social and national suppression"; in the following parts it points out the strengthening of Hlinka's Slovak People's Party not mentioning its major player but does not forget to underline that the Party "relied mainly on the Catholic clergy", that its programme consisted "not only of the fight for the autonomy of Slovakia, but the Ludaks made efforts to win the competition with the Czech bourgeoisie and to gain control over Slovakia." The authors deliberately set the Communist national programme as the antipole to Ludak's national programme whereas it was reportedly

55 Joza, Jaroslav - Butvin, Jozef - Červinka, František: Dejepis 8, pre ôsmy ročník základnej devätročnej školy Bratislava, SPN : 1969, 250 pp, p. 241-243, 243.

56 Butvinová, Mária - Marianiová, Olga .- Dullová, Valéria: Dejepis pre 8. ročník ZDŠ. I. vydanie Bratislava, SPN : 1975.243 pp. 
"based upon the right to self-determination of the nations and showed a way to the Slovak people how to eliminate both the national and social suppression".

The language of the textbooks of the mid-1970s and the turn of the 1980s definitely changed, seemingly to their benefit. The outwardly unbiased, more civilized professional vocabulary is definitely preferred to the former dramatically presented national stories with their plots and metaphysical categories of the fight between the good and evil; it is accompanied by the use of the contemporary professional terminology even in the text designated for primary schools. Is it, however, the form of familiarizing the young generation in a more effective and functional manner with the past, the building of the feelings of togetherness with their community? It seems that a certain role was played by the knowledge that the schemes and approaches of the 50s could not be reused. Still, the redressed old objectives formed the results which helped "the building" of a low prestige of the Slovak history education persisting up to now.

The textbooks of the last stage of the Communist regime made Hlinka, at the best, a highly schematized figure with definitely negative traits but in most cases they tried to neglect his place in Slovak history. Similarly as in the textbooks, there is not a single reference to him in the workbooks and reading-books, which received a wider use in the teaching as an aid in connection with the introduction of the didactic method of the application of "school sources". Almost absolute abandonment of any questions about the place of individuality in (first of all modern) history is even more depressing in these materials. ${ }^{58}$

The text of the extensive secondary-school textbook of Czechoslovak history published in 1975, which synthesized history curriculum starting from the beginnings of the settlement of the "Czechoslovak" territory up to the second half of the 1970s - up to "the building of the developed socialist society in Czechoslovakia", as determined by the period terminology, and which was also several times reprinted, makes an impression of a very cultivated and understandable text. ${ }^{59}$ The schemes that sound worst and empty terminology are limited to a minimum. It is just this

57 Dullová, Valéria -Valachová, Anna - Beňo, Ladislav - Dzugas, Jozef -Pleva, Ján.: Dejepis pre 9. ročník základnej devätročnej školy, SPN, Bratislava: 1971, III. vydanie, SPN Bratislava: 1976256 pp., p. 18, 42, 65-66. The omission of A. Hlinka's direct activities is all the more striking as the players of less important political parties than HSL'S are mentioned in the texts.

58 For all: Marianiová -BUTVINOVÁ- Vengřinová: Pracovný zošit k dejepisu pre 8. ročník základnej devätročnej školy. Bratislava, SPN : 1972. 102 pp, p. 72-80, 80-90, 97.

59 Ratkoš, Peter - Butvin Jozef - Kropilák Miroslav -VARTÍKOVÁ, Marta: Dejiny Československa. Učebné texty pre 3. a 4. ročník gymnázia a pre 2. ročník strednej odbornej školy. 5. vydanie, Bratislava, SPN: 1980, 451 pp. The text is focused on the curriculum for two secondary-school years. It is interesting that the textbook was still recommended as an aid for the preparation for admission exams for university study of history and for the study at the Faculty of Law of Comenius University in the 1990s. 
textbook where a student will find at last a reference to the well-known slogan about "the unsuccessful thousand-year marriage with the Hungarians as an adequate reason to split up". (It is attributed to the standpoint of all leading representatives of all political directions of the National Party at the conference on May 24, 1918.) He will find there also extensive positive references to the role of the Slovak exile in the USA in the crystallization of the attitudes of the Slovak representation towards the concept of independent Czechoslovakia (of course, interpreted as "presentations of the Slovak proletariat"), a really striking is a reference to F. Skyčák, another representative of the Slovak People's Party from among priests, otherwise not found in textbooks at all. ${ }^{60}$ A persisting schematization of the explanatory text is striking again when getting familiar with the educational portrayal of Andrej Hlinka. He is introduced as a representative of the "pronounced reactionary interests", a reference to Černová got along, of course, without mentioning "Hlinkaesque" connections and, after the description of Hlinka's interwar activities, his portrayal acquired all old-new clichéd contours. (The text did not forget to associate his name with the later formation of Hlinka's Guard. ${ }^{61}$ )

In the textbook, which was published just prior to the political changes, we can find, however, a tendentious interpretation of modern history and the Slovak past, which became its own caricature. History for the third year of secondary schools of 1987 attempted to fulfil the task of a repeated synchronized presentation of the curriculum of national and world history from the 20th-century period. ${ }^{62}$ This resulted not only in a significant disproportion in the representation of the themes of national and world history, a minimum space for the Slovak issues, but mainly the explanation was based upon all stereotype ornate phrases of the communist doctrine. Therefore, the view on Hlinka may not be surprising. The text provides only a three-line and again indirect information: the student would learn that "the exploitative method of the Czech capital in Slovakia enabled the growth of the clerical-fascist opposition movement represented by Hlinka's Slovak People's Party", which "represented a substantial part of the forces in the republic which attempted at a revision of the Versailles Peace Treaty and the break-up of Czechoslovakia". ${ }^{3}$

60 Ratkoš, Peter - Butvin Jozef - Kropilák Miroslav -Vartíková, Marta: Dejiny Československa. Učebné texty pre 3. a 4. ročník gymnázia a pre 2. ročník strednej odbornej školy. 5. vydanie, Bratislava, SPN: 1980, 451, p. 287, 282, $284,270$.

61 Ratkoš, Peter - Butvin Jozef - Kropilák Miroslav -Vartíková, Marta: Dejiny Československa. Učebné texty pre 3. a 4. ročník gymnázia a pre 2. ročník strednej odbornej školy. 5. vydanie, Bratislava, SPN: 1980, 451, p. 270-271, 302, 306, 317-318, 334-335.

62 Cambel, Samuel - Sýkora, Jaroslav - Macek, Zdeněk - Kamenec, Ivan: Dejepis pre 3. ročník gymnázia. Bratislava, SPN: 1987, 318 pp.

63 Cambel, Samuel - Sýkora, Jaroslav - Macek, Zdeněk - Kamenec, Ivan: Dejepis pre 3. ročník gymnázia. Bratislava, SPN: 1987, p. 73. 
The consequences of the deformed national narrations could not certainly manifest themselves immediately. It is also difficult to find out how they gradually affected the equalized Slovak society. Partial personal evidence of the contemporary teachers often reminded that their recipients - pupils and students - when seeking models or identifying themselves with some sides and figures of the past often simply preferred events from the Czech (or world) history; however, these assertions lack the supporting empirical data. (A well-known example from the Slovak school practice is, nevertheless, a general unpopularity of the history curriculum concerning the national emancipation, i.e. the issues which should or might have one of the best responses among young people.) The Slovak society started to perceive more realistically "the presence of the past", the impact of historical consciousness and various types of historical memory of the members of their own community on the current social situation only after the change of political regime. At the same time, it started discovering that even the studying youth often lack the awareness and understanding of the stereotypes and prejudice generated by the past; it is still a hot issue to define more exactly the degree of formal and informal educational factors and their mutual interaction.

It is just the figure of Andrej Hlinka who came out of the non-self-confident acceptance of own past within Slovak society. His name became a symbol, motto and slogan to which the Slovak community naturally responded throughout its historical development and complicated cultural transformation that it went through in the 20th century. The fact that Slovak history textbooks were unable to respond to it sufficiently effectively during the long period became one of the symptoms of a long-lasting crisis of the Slovak history teaching.

The impact of history textbooks published after the change of political situation has not been defined yet. This is specifically proven by our partial empirical research of the attitudes of the students beginning their study of history teaching who passed both stages of history education (at both primary and secondary schools) where these new textbooks were used. The sample of respondents participating in the survey is relatively small by size (40 students of the 1st and 2nd year of Bachelor study of history teaching), but we consider its internal layering important: the respondents come from various regions of Slovakia (consequently, they attended different primary and secondary schools while, at the same time, theoretically they could have familiarized themselves with history textbooks published after 1989, their knowledge and attitudes have not been yet influenced by the university study - at least by the study as of the period of modern history while their deeper interest in 
history can be expected). We were interested in particular in the quality and ties of the "memories" of the figure of Hlinka. ${ }^{64}$

The structure of the questionnaire ( 22 items, closed questions and open questions) allowed to collect certain factual data (knowledge) and the attitude values as well, and to identify the sources forming the contemporary historical memory of the young generation. A group of sixteen historical figures in the introductory part of the questionnaire was chosen so that it would reflect the hottest current discussions held in Slovak society in connection with their names (including specific discussions about the representation of respective personages in history teaching). Therefore, the created set corresponds to a certain degree with the set of the names of personages from the surveys mentioned in the beginning of our study but it is not identical with them. ${ }^{65}$ The scale of preferences (a choice of three names to which the respondent had to attach short concepts by which he/she would characterize them based on his/ her personal attitude) also corresponds to a certain degree with other older surveys. It confirms a clichéd perception of Slovak personages persisting also in the environment of university students beginning their more serious study of history. Even more so, in our opinion, the strength of the Slovak traditional historical "codes" is presented. In the fourteen answers in which Andrej Hlinka was chosen in the liking preferences, the following personal "key words" were indicated: SLS (the Slovak People's Party), the priest, self-giving for his people, engaged in politics, "Life for God, freedom for the nation", defender of the Slovak rights, a significant political figure, national revivalist, HSL'S (Hlinka's Slovak People's Party), autonomy and equality, the father of the nation, Černová, Christianity, independence. (We presume that the slogan "Life for God..." appeared in these personal attitudes only after the respondent found the wording of the subsequent questions in the questionnaire) ${ }^{66}$

64 Andrej Hlinka cez „objektív“ empirického prieskumu a analýzy učebníc dejepisu [Andrej Hlinka through the lens of empirical research and analysis of history textbooks]. The research and survey via questionnaires done by the Department of History of the Faculty of Pedagogy, Comenius University, academic years 2014-2016 (Anna Bocková - Mária Tonková). Data collection: 21-22 Sep 2015. The results of the survey via questionnaires: the Library of the Department of History of the Faculty of Pedagogy, Comenius University and personal archive of A.B., M.T. We have selected only some data from the survey.

65 A certain specific exception: Maria Teresa was selected in particular with regard to the current Slovak discussions about personages in history teaching and for the same reason the names of Hungarian revolutionists, respectively politicians appeared in this selection.

66 Table No 1: Preferences of personages with the specification of key terms or collocations which characterize the given personage: a/ Maria Teresa - 24 choices; b/ Sándor Petöfi - 1 choice; c/ Ludovít Štúr - 32 choices; d/ Lajos Kossuth - 0 choices; e/ Andrej Hlinka - 14 choices; f/ Tomáš G. Masaryk - 5 choices; g/ M. R. Štefánik - 22 choices; h/ Milan Hodža - 1 choice; ch/ Jozef Tiso - 5 choices; i/ Edvard Beneš - 0 choices; j/ bishop Vojtašśák - 2 choices; k/ bishop Gojdič - 2 choices; 1/ general Golian - 2 choices; m/ Alexander Dubček - 11 choices; n/ Gustáv Husák - 0 choices; o/ Václav Havel - 0 choices. Andrej Hlinka through "the lens", Transcript and interpretation of questionnaires, p. 7-8. 
The traditional strength and, on the other hand, vague contours of the attitudes towards Andrej Hlinka are even better documented by the answers to the questions which try to verify more exactly on which basis Hlinka's "messages" are surviving in the memory and consciousness of young people. Very frequent (50-60\%) are short statements using the naming of some events but not formulating own attitude. At the same time, a substantial part of answers to the introductory question of this part of the survey already showed that many students perceive the figure of Andrej Hlinka in the context of the period of the war Slovak State, partially in connection with the formation of the interwar Czechoslovak Republic; the significance and international impact of the Černová events are frequently repeated; the perception of the issues related to the Slovak development in the interwar Czechoslovak Republic which represented the fundament of Hlinka's political activities is limited to short and unclear statements about the fight for autonomy. Although he died in 1938, his name was imprinted in the memory of a part of youth alongside the name of the leading political power of that period. However, the range of such perception of Hlinka by the respective respondents is not quite clear - some answers indicate an (incorrect) "appropriation of his name by the paramilitary organisation of Hlinka's Guard", other answers could not simultaneously specify whether in such case they would identify with the given state; we can find, however, also answers speaking about "a deeply faithful Catholic priest, and this was projected also into his politics ... and he headed Hlinka's National Guard" (the question was about Hlinka's message for the respondent). We can find also more exactly defined answers about "the brave and active representative of the fight for independence of Slovakia", or "the fighter for the enforcement of autonomy" ${ }^{67}$

The answers to subsequent questions repeated the variants of the outlined ways of thinking. More specifically, directed questions pointed out also patchy knowledge, wrongly linking together many basic contexts of Slovak history (Hlinka as "the leading personality of the party which collaborated with Germany during the Second World War and partially adopted fascist attitudes"). The complete, more or less positive image of the "message" of Andrej Hlinka was not changing. ${ }^{68}$ On the other hand, many answers were able to properly name the sources of the problems: from associating wrongly his person with the activities of mass organisations named after him posthumously up to his defamation by communist historiography, even his nationalism or religious intolerance. We should not be probably surprised that these are mostly the answers of the respondents who stated that they talked about the figure of Hlinka

67 Andrej Hlinka cez objektív, Prepis a interpretácia, question No 1, questions No 5, 6, p. 9-10, 12.

68 Andrej Hlinka cez objektív, Prepis a interpretácia, question No 1, questions No 5, 6, questions No $4,6,13$., p. 11-12, 17-18. 
also out of school, at home or with friends (but only 14 respondents indicated such talks), or respectively they familiarized themselves with other out-of-school sources of information. ${ }^{69}$ According to our assessment, it is not a surprising fact that students "expanded", in other words provided the most extensive and mostly positive answers to the questions of how they perceive the designation of Hlinka as "the father of the nation". Only 15 respondents did not express their opinion. It is true, however, that here we also find sober and more critical students' reflections on the uncritical and pathetic view of the personality, and this can be justified by the era or a note that large groups of the nation quite justly do not have to accept such designation etc. ${ }^{70}$

\section{TRANSLATION: Evo SCIRANKOVÁ}

69 Andrej Hlinka cez objektív, Prepis a interpretácia, question No 1, questions No 5, 6, questions No $4,6,13$., p. 11-12, 17-18., question No 8, p. 14; question No 2, p. 10.

70 Andrej Hlinka cez objektív, Prepis a interpretácia, question No 1, questions No 5, 6, questions No 10, 11, p.15-17.

BIBLIOGRAPHY

Andrej Hlinka - vodca slovenského národa, vol. II: Drama and drama songs, ed. by F. Urbánek, Trnava 1938

Andrej Hlinka - vodca slovenského národa, vol. III: Symbolické prostné na národné piesne, Dramatizácie, symbolické, rojové a skupinové cvičenia, ed. by A. Zemančík, Trnava 1938

Butvinová M., Marianiová O., Dullová V., Dejepis pre 8. ročník ZDŠ, Bratislava 1975

Cambel S., Sýkora J., Macek Z., Kamenec I., Dejepis pre 3. ročník gymnázia, Bratislava 1987

Dullová V., Valachová A., Beňo L., Dzugas J., Pleva J., Dejepis pre 9. ročník základnej devätročnej školy, Bratislava 1971

Dullová V., Valachová A., Beňo L., Dzugas J., Pleva J., Dejepis pre 9. ročník základnej devätročnej školy, 3rd ed., Bratislava 1976

Dunaj, Dejepis pre 6. postupný ročník slovenských ludových škôl, Trnava 1939

Dunaj, Učebnica dejepisu pre slovenské ludové školy 1941, 2nd ed., Trnava 1941

Encyklopédia Slovenska : III. zväzok. K-M., Bratislava 1979

Flegl M., Historik Josef Klik. Nad knihou Bohumila Jirouška in: „Rodopisná revue on-line”, 2013,

No 25/15, vol.1, http://rodopisna-revue-online.tode.cz/2013-1/25-27_flegl-klik.pdf

Hrnčír F., Macht A., Slovenské obrázkové dejiny národa československého, Praha 1924

Hrušovský F., Slovenské dejiny. Učebnica pre IV. triedu slovenských stredných škôl, Matica slovenská 1940

Hrušovský F., Slovenské dejiny. Učebnica pre 4. triedu slovenských stredných škôl, Bratislava 1944

Joza J., Butvin J., Červinka F., Dejepis 8, pre ôsmy ročník základnej devätročnej školy, Bratislava 1969

Kázmerová, L., Vznik a rozvoj slovenského školstva In: Slovensko v medzivojnovom Československu, Bratislava 2012, pp. 154-166.

Koreň J., Dejiny československého národa.Dejepis pre slovenské l’udovés školy a pre opakovacie školy, Prešov 1922 Krivý V., Feglová V., Balko D., Slovensko a jeho regióny: sociokultúrne súvislosti volebného správania, Bratislava 1996 Krivý V., Kolektíne identity na súčasnom Slovensku. Pramenná publikácia dát zo sociologického prieskumu, Bratislava 2004 
Kulhánek F., L'udové dejiny československé. I. čiastka l'udovej vlastivedy, Banská Bystrica 1920

Kulhánek F., L'udové dejiny československé. I. čiastka l'udovej vlastivedy, 2nd ed., Banská Bystrica 1922

Letz R., Andrej Hlinka vo svetle dokumentov, Bratislava 2014

Lipták L'., Storočie dlhšie ako sto rokov, Bratislava 1999

Mach A. Štefánik a Hlinka - jeden duch, náš duch!, “Gardista” No 1, vol. 14, 6. 05. 1939

Macho P. M.R., Štefánik a A. Hlinka v básnických a komemoratívnych textoch. Historická osobnost' ako národný symbol a jeho štylizácia, „Studia Academica Slovaca” 2005, vol. 34, pp. 367-396.

Marianiová O., Butvinová M., Vengřinová: Pracovný zošit $k$ dejepisu pre 8. ročník základnej devätročnej školy, Bratislava 1972

Mederly K., Andrej Hlinka - jediná autorita prýštiaca z duše slovenského národa, „Slovák”, No 21, vol. 96, 26. 04. 1939, p. 1-2.

Nedbálek, L., Pojem vyučovania vlastivedy ako predmetu l'udovej školy, „Národná škola” 1923, vol.1, p. 268-269.

Němec M., Škola mezi národem a státem. Dějepis na středních školách v medziválečném Československu, in: „Historia scholastica” 2013, No I, vol. 1

Nora P., Mezi pamètí a historii: problematika míst, transl. by H. Thein, „Cahiers du CEFRES” No 13, Praha 1998

Očenášová S., Schválená minulost'. Kolektívna identita v československých a slovenských učebniciach dejepisu 1918-1989, Košice 2010

Pekař J., Dejiny československé pre najvyššiu triedu stredných škôl. Spracoval Josef Klik, poslovenčil Cyril Chorvát, Praha 1938

Pekař J., Dějiny československé pro nejvyšši třídy škol středních, Praha 1921

Pekař J., Klik J., Dějiny československé pro nejvyšší třídy škol středních, 2nd ed., Praha 1937

Petrenko, Hollý, Janega, Stručné dejiny Československa. II. nezmenené vydanie, Bratislava 1947

Ratkoš P., Butvin J., Kropilák M., Vartíková M., Dejiny Československa. Učebné texty pre 3. a 4. ročník gymnázia a pre 2. ročník strednej odbornej školy, $5^{\text {th }}$ ed., Bratislava 1980

Rogul'ová J., Dejiny a patriotizmus mladých Slovákov, „Nová história” 2001, No 1, vol. 4

Rogul'ová J., Valachová D., Dejiny očami gymnazistov, „Nová história” 2001, No 1, vol. 3

Rogul'ová, J., Autonómne Slovensko, in: Pramene k dejinám Slovenska a Slovákov XIIIa - Slováci a druhá svetová vojna, Bratislava 2015.

Rychlík J., Rozpad Československa. Československé vztahy 1989-1992, Bratislava 2002

Seton-Watson R. W., Nábožensko-cirkevný problem, „Lidové noviny” 1924, No 32, vol. $27 / 1$ (49) Seton-

Watson R. W., Slovakia then and now., A political Survey, London-Prague 1931

Šikura J., Učebnice dějepisu in: První sjezd československých historiků 1937, Praha 1938

Sivák J., Slovak educational system and its growth, „Slovák”, No 26, vol. 61, 14.3.1944, pp. 19-21. Pramene

k dejinám Slovenska a Slovákov XIIIa - Slováci a druhá svetová vojna, Bratislava 2015.

Školník pre školy evanjelické augsburského vyznania (coll.), 2nd ed., Senica 1906

Slovenský biografický slovník. III. zväzok K-L, Martin 1989

Tonková M., Civics and Civic Education in the Slovak Republic - its Tradition and Current Situation and Model in Relation to History, „Prace Historyczne: Zeszyty Naukowe Uniwesytetu Jagiellońskiego”, No 142, vol. 2, pp. 219-242.

Valachová D., Rogul'ová J., Čo o sebe vieme? Dejiny očami menšiny a väčšiny, „História” 2003, vol. 3

Web pages:

http://www.andrejhlinka.sk/povedali-o-hlinkovi/

http://www.cefres.cz/pdf/c10/nora_1996_mezi_pameti_historii.pdf 